\begin{tabular}{|c|c|c|}
\hline 回 & 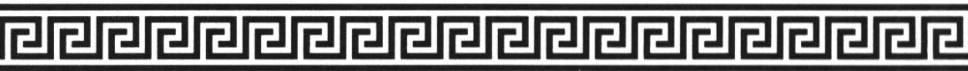 & 回 \\
\hline 包 & & 무 \\
\hline & & 可 \\
\hline & & 包 \\
\hline & & 미 \\
\hline 迎 & & 它 \\
\hline 勻 & Volume 1: The Basic Amnal & 山 \\
\hline إن & Volume 7: The Memoir & एᄂ \\
\hline ص & & مإ \\
\hline 岛 & Ssu-ma Ch’ien & 눔 \\
\hline 남 & Edited by William H. Nienhauser, Jr. & 道 \\
\hline مإن & Translated by Tsai-fa Cheng, William H. Nienhauser, Jr., & بإ \\
\hline 눈 & Robert Reynolds, and Lu Zongli, with Chu-Ming Chan (on Volume 7) & 닌 \\
\hline 可 & The first complete English translation of & 勻 \\
\hline 山्ل & Chinese history. This project will result in the first complete & च \\
\hline 니 & translation (in nine volumes) of the Shih chi (The Grand Scribe's & 山्. \\
\hline 山 & Records), one of the most important narratives in traditional China. & 미 \\
\hline 山 & Compiled by Ssu-ma Ch'ien (145-c.86 B.C.), known as the & \\
\hline 山 & Herodotus of China, it draws upon most major early historical works & 山्. \\
\hline 님 & and was the foremost model for style and genre in Chinese history & 남 \\
\hline |े & A.D., and through the & إن \\
\hline 勻 & early twentieth century from some & 包 \\
\hline 可 & Volume 1,307 pages, cloth $\$ 34.95$ & 可 \\
\hline చ & Volume 7,448 pages, cloth 849.95 & ] \\
\hline 邖 & & 밈 \\
\hline एu & n & 可 \\
\hline 包 & Records), one of the most important narratives in traditional China. & 岛 \\
\hline 它 & Herodotus of China it draws unon most maior early historical works & 包 \\
\hline 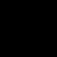 & and was the foremost model for style and genre in Chinese history & 包 \\
\hline 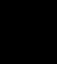 & and literature through the eleventh century A.D., and through the & 山 \\
\hline بإ & early twentieth century from some genres. & 남 \\
\hline 무 & Volume 1,307 pages, cloth $\$ 34.95$ & 미 \\
\hline 它 & Volume 7, 448 pages, cloth $\$ 49.95$ & ] \\
\hline 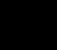 & & 可 \\
\hline L & & 미 \\
\hline ] & houketeres or & 司 \\
\hline
\end{tabular}


THE EARLY CHINA SPECIAL MONOGRAPH SERIES

announces

\section{EARLY CHINESE TEXTS: A BIBLIOGRAPHICAL GUIDE}

\section{Edited by MICHAEL LOEWE}

This volume includes descriptive notices on sixty-four literary works written or compiled before the end of the Han dynasty. Three dozen leading scholars from the United States and Europe summarize the subject matter and contents, present conclusions regarding authorship, authenticity and textual history, and indicate outstanding problems that await solution. Each item is supported by lists of traditional and modern editions, commentaries, translations and research aids. The sixty-four notices total nearly five hundred pages, with additional appendices and a 34-page index of scholars. This volume can be purchased from the Institute of East Asian Studies, Berkeley, for \$35, and in Europe through Sinobiblia for $€ 20$ (or the equivalent ECU).

Please direct orders to:

Publications

Institute of East Asian Studies

University of California

2223 Fulton Street

Berkeley CA 94720
Sinobiblia

15 Durham Road

Harrow, Middx.

HA1 4PG

United Kingdom 


\title{
Birdtrack Press
}

\author{
鳥跡排字
}

\begin{abstract}
B IRDTRACK PREss specializes in setting the type for sinological publications that integrate printed Chinese with alphabetic text: we produce camera-ready copy at an affordable price. We routinely set the unusual characters sinologists require, including custom logographs for variant or archaic forms. We offer a large selection of alphabetic typefaces, and can create special diacritics or phonetic symbols to match. We know how to meet publishers' page specifications, and are happy to discuss technical issues with design and production staff. We also work directly with authors, and have the expertise and experience in sinological computing and typography to ensure professional results. Please note our new address:
\end{abstract}

David W. Goodrich 26 McKinley Avenue New Haven, CT 06515

(203) 389-7789 


\section{CHINA RESEARCH \\ MONOGRAPHS \\ Imperial China's Last \\ Classical Academies \\ Social Change in the Lower \\ Yangzi, 1864-1911 \\ Barry C. Keenan \\ $\$ 16.00$}

Chinese Archives: An

Introductory Guide

Ye Wa and Joseph W. Esherick $\$ 23.50$

\section{Negotiating Ethnicities} in China and Taiwan

Melissa Brown, ed. Introduction by Stevan Harrell $\$ 20.00$

\section{The Chinese Staff}

\section{System}

A Mechanism for Bureaucratic

Control and Integration

Wei $\mathrm{Li}$

$\$ 8.00$

\section{China's Brain Drain to} America

Changgui Chen and David Zweig $\$ 13.50$
BACK BY POPUlaR DEMAND

A Survey of Taoist

Literature, Tenth to

Seventeenth Centuries

Judith M. Boltz

Reprinted with corrigenda

$\$ 25.00$ (no discount available)

Advance prepaid orders only

Available May 1995

\section{CHINESE POPULAR}

CULTURE PROJECT

Ritual and Scripture

in Chinese

Popular Religion

Five Studies

David Johnson, ed.

$\$ 15.00$ (no discount available)

\section{EARLY CHINA}

\section{Early China 19}

Annual journal of the Society for the Study of Early China

$\$ 30.00$ (no discount available)

Early Chinese Texts

A Bibliographical Guide

Michael Loewe, ed.

$\$ 35.00$ (no discount available)
KOREA RESEARCH

MONOGRAPHS

A Korean Confucian

Encounter with the

Modern World

Yi Hang-no and the West

Chai-sik Chung

$\$ 20.00$

Prospects for Change

in North Korea

Tae Hwan $O k$ and Hong Yung

Lee, eds.

$\$ 20.00$

RESEARCH PAPERS AND

POLICY STUDIES

Cultural Nationalism

in East Asia

Representation and Identity

Harumi Befu, ed.

$\$ 17.00$

INDOCHINA RESEARCH

MONOGRAPHS

Vietnam Population

Dynamics and Prospects

Judith Banister

$\$ 10.00$

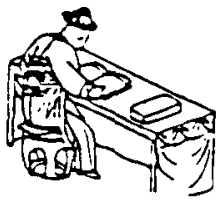

\section{Call for manuscripts for all series}

University of California IEAS Publications 2223 Fulton Street \# 2318 Berkeley, California 94720-2318 510/643-6325 (telephone) 510/643-7062 (facsimile) easia@uclink.berkeley.edu (E-mail)

All orders must be prepaid. VTSA and Mastercard accepted. Califormia residents, add $8.25 \%$ sales tax.

Shipping: \$2.50, one book; \$1.00 each additional book 


\section{INTERNATIONAL AND AREA STUDIES}

\section{Richard Buxbaum, Dean}

International and Area Studies at the University of California, Berkeley, comprises four groups: international and comparative studies, area studies, teaching programs, and services to international programs.

\section{INSTITUTE OF EAST ASIAN STUDIES UNIVERSITY OF CALIFORNIA, BERKELEY}

The Institute of East Asian Studies, now a part of Berkeley International and Area Studies, was established at the University of California at Berkeley in the fall of 1978 to promote research and teaching on the cultures and societies of China, Japan, and Korea. It amalgamates the following research and instructional centers and programs: the Center for Chinese Studies, the Center for Japanese Studies, the Center for Korean Studies, the Group in Asian Studies, the Indochina Studies Project, and the East Asia National Resource Center.

\section{INSTITUTE OF EAST ASIAN STUDIES}

Director: Frederic E. Wakeman, Jr.

Associate Director: Joyce K. Kallgren

Assistant Director: Joan P. Kask

Executive Committee: Mary Elizabeth Berry

Lowell Dittmer

Thomas Gold

Thomas Havens

Joyce K. Kallgren

Joan P. Kask

Hong Yung Lee

Jeffrey Riegel

Ting Pang-hsin

Wen-hsin Yeh

\section{CENTER FOR CHINESE STUDIES}

Chair: Wen-hsin Yeh

CENTER FOR JAPANESE STUDIES

Chair: Mary Elizabeth Berry

CENTER FOR KOREAN STUDIES

Chair: Hong Yung Lee

GROUP IN ASIAN STUDIES

Chair: Lowell Dittmer

INDOCHINA STUDIES PROJECT

Chair: Douglas Pike

EAST ASIA NATIONAL RESOURCE CENTER

Director: Frederic E. Wakeman, Jr. 


\section{CONTENTS}

\section{ARTICLES}

Redaction Criticism and

the Early History of Taoism

Harold D. Roth

A First Reading of the

Mawangdui Yijing Manuscript

Edward L. Shaughnessy

The Yin-Yang Texts from Yingqueshan:

An Introduction and Partial Reconstruction, with Notes on their Significance in Relation to Huang-Lao Daoism

Robin D.S. Yates

REVIEWS

Confucian Enlightenment

Eske J. Møllgaard

Philology, Filiation, and Bibliography in

the Textual Criticism of the Huainanzi:

A Review Article

David B. Honey

BIBLIOGRAPHY

Shigaku Zasshi Summary

of Japanese Scholarship for 1992 Lothar von Falkenhausen 